\title{
Calcium Waves in Skinned Cardiac Myocytes Evoked by Two-Photon Excitation Photolysis of Caged Calcium
}

\author{
Masato KONISHI, Toshikazu YAMASHITA* ${ }^{*}$ Shinsuke NAKAYAMA, ${ }^{\dagger}$ and Shinichiro KOKUBUN* \\ Department of Physiology, Tokyo Medical University, Tokyo, 160-8402 Japan; \\ *Advanced Research Center, School of Medicine, Nihon University, \\ Tokyo, 173-8610 Japan; and \\ † Department of Cell Physiology, Nagoya University Graduate School of Medicine, \\ Nagoya, 466-8550 Japan
}

\begin{abstract}
In rat ventricular myocytes chemically skinned with saponin, a local rise of $\left[\mathrm{Ca}^{2+}\right]$ was achieved by two-photon excitation photolysis (TPP) of the caged $\mathrm{Ca}^{2+}$ compound 1-(2nitro-4,5-dimethoxyphenyl)- $N, N, N^{\prime}, N^{\prime}$-tetrakis[(oxycarbonyl)methyl]-1,2-ethanediamine (DM-nitrophen). Confocal $\mathrm{Ca}^{2+}$ images, by use of fluo3 , were simultaneously collected. TPP of DM-nitrophen induced $\mathrm{Ca}^{2+}$ waves propagating over the myocyte, and the local rise of $\left[\mathrm{Ca}^{2+}\right]$ at the site of photolysis sustained for $50-60 \mathrm{~ms}$. These
\end{abstract}

TPP-induced $\mathrm{Ca}^{2+}$ events were completely suppressed by ryanodine $(10 \mu \mathrm{M})$, suggesting that $\mathrm{Ca}^{2+}$ release resulting from TPP of DM-nitrophen triggered regenerative $\mathrm{Ca}^{2+}$ release from the neighboring sarcoplasmic reticulum. The present techniques should be useful to investigate the interaction of elementary $\mathrm{Ca}^{2+}$ events, the process leading to global $\mathrm{Ca}^{2+}$ movements, in cardiac myocytes and other types of cells. [Japanese Journal of Physiology, 51, 127-132, 2001]

Key words: cardiac myocytes, two-photon excitation, caged calcium.

$\mathrm{R}$ the use of confocal microscopy, revealed localized elementary $\mathrm{Ca}^{2+}$ events, such as $\mathrm{Ca}^{2+}$ sparks and quarks, in numerous types of cells, including nonexcitable cells (e.g., [1-8]). These elementary $\mathrm{Ca}^{2+}$ events are produced by activation of a single or a group of $\mathrm{Ca}^{2+}$ release channel(s) of the intracellular $\mathrm{Ca}^{2+}$ stores: ryanodine receptors and $\mathrm{InsP}_{3}$ receptors. Under appropriate conditions, a local rise of intracellular $\left[\mathrm{Ca}^{2+}\right]$ sequentially activates adjacent $\mathrm{Ca}^{2+}$ release channels $\left(\mathrm{Ca}^{2+}\right.$-induced $\mathrm{Ca}^{2+}$ release), resulting in $\mathrm{Ca}^{2+}$ waves to propagate over the whole cell [9].

Two-photon excitation is an optical technique recently applied in biology fields that can be used to photolyze caged compounds only at the focal point. Two-photon excitation photolysis (TPP) of caged
$\mathrm{Ca}^{2+}$ has been applied to induce global $\mathrm{Ca}^{2+}$ movements in isolated cardiac myocytes and neurons under whole-cell patch clamp conditions $[10,11]$. In these whole-cell patch clamp experiments, however, the precise control of the intracellular environment (e.g., cytoplasmic $\left.\left[\mathrm{Ca}^{2+}\right]\right)$ appeared difficult because of limited intracellular perfusion through the patch pipette.

In the present study, we applied TPP to produce a local rise of $\left[\mathrm{Ca}^{2+}\right]$ in skinned (or permeabilized) cardiac myocytes in which various substances were in rapid equilibrium between extracellular fluid and cytoplasm [12]. Changes in $\left[\mathrm{Ca}^{2+}\right]$ were simultaneously monitored by a fluorescent $\mathrm{Ca}^{2+}$ indicator fluo-3 with laser-scanning confocal detection (operating in ordinary one-photon excitation mode). By optimizing the composition of "internal solutions," $\mathrm{Ca}^{2+}$ waves were

Received on November 29, 2000; accepted on December 28, 2000

Correspondence should be addressed to: Shinsuke Nakayama, Department of Cell Physiology, Nagoya University Graduate School of Medicine, 65 Tsurumai, Showa-ku, Nagoya, 466-8550 Japan. Tel: +81-52-744-2045, Fax: +81-52-744-2048, E-mail: h44673a@nucc. cc.nagoya-u.ac.jp

Abbreviations: TPP, two-photon excitation photolysis; EDTA, ethylenediamine- $N, N, N^{\prime}, N^{\prime}$-tetraacetic acid; DM-nitrophen, 1-(2-nitro-4,5-

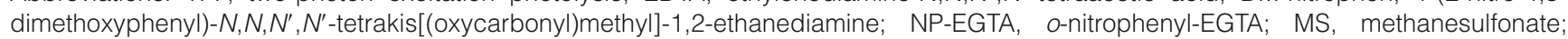
InsP $\mathrm{P}_{3}$, inositol trisphosphate; MOPS, 3-morpholinopropanesulfonic acid; $\left[\mathrm{Ca}^{2+}\right]$, free $\mathrm{Ca}^{2+}$ concentration; $\left[\mathrm{Mg}^{2+}\right]$, free $\mathrm{Mg}^{2+}$ concentration; SR, sarcoplasmic reticulum. 
highly reproducible upon TPP of caged $\mathrm{Ca}^{2+}$ at any location of the myocytes.

\section{Methods}

Preparation of skinned cardiac myocytes. Male Wistar rats weighing 300-400g were anesthetized with sodium pentobarbital $(100 \mathrm{mg} / \mathrm{kg}$ body weight, intraperitoneal). The animals were treated in accordance with the Guiding Principles for the Care and Use of Animals in the Field of Physiological Sciences published by the Physiological Society of Japan. The heart was quickly excised, and single ventricular myocytes were enzymatically isolated, as described previously [13]. After enzymatic digestion with $0.2 \mathrm{mg} / \mathrm{ml}$ collagenase (Collagenase S-1, Nitta Zerachin, Tokyo, Japan) and $0.04 \mathrm{mg} / \mathrm{ml}$ protease (type XIV, Sigma, St. Louis, MO, USA), cells were stored in a low $\mathrm{Ca}^{2+}$-Tyrode solution containing (mM) 135 $\mathrm{NaCl}, 5.4 \mathrm{KCl}, 0.2 \mathrm{CaCl}_{2}, 1.0 \mathrm{MgCl}_{2}, 0.33 \mathrm{NaH}_{2} \mathrm{PO}_{4}$, 5.0 glucose, and 10 HEPES ( $\mathrm{pH} 7.4)$ at $6^{\circ} \mathrm{C}$ until used. The myocytes were skinned with $100 \mu \mathrm{g} / \mathrm{ml}$ saponin (Sigma) for $1 \mathrm{~min}$ in the relaxing solution containing (mM) $128 \mathrm{KMS}, 4.57 \quad \mathrm{MgMS}_{2}, 4.39$ $\mathrm{Na}_{2}$ ATP, 1.0 EGTA, 20 MOPS, and pH 7.2. After a washout of saponin, skinned cells (length $\sim 100 \mu \mathrm{m}$, width $\sim 20 \mu \mathrm{m}$ ) were incubated in the photolysis solution and subsequently settled in an experimental chamber ( $30 \mu \mathrm{l}$ in volume) on the stage of an inverted microscope (DM IRBE, Leica, Wetzler, Germany). All experiments were carried out at $26-28^{\circ} \mathrm{C}$.

Two-photon excitation photolysis and simultaneous $\mathrm{Ca}^{2+}$ measurements. A Ti:sapphire laser (Tunami 3960, Spectra Physics, Mountain View, CA, USA) was pumped by a diode-pumped continuous-wave visible laser (Milennia V, Spectra Physics). The pulsed laser system was operated at $710-715 \mathrm{~nm}$ (half-maximal width $53 \mathrm{fs}$, repetition rate $82 \mathrm{MHz}$ and $340 \mathrm{~mW}$ ). This pulsed laser light and visible laser light from a confocal unit (TCS NP, Leica) were introduced through a dichroic mirror (reflecting wavelength $>660 \mathrm{~nm}$ ) to a $63 \times$ water-immersion objective lens (NA 1.20, PL APO $63 \times 1.20 \mathrm{~W}$ CORR, Leica) and focused on the myocyte on the microscope stage. For TPP of DM-nitrophen [14], the pulsed laser light was delivered for $64 \mathrm{~ms}$ via a mechanical shutter (F77-4, Copal, Tokyo; F77 controller, Surugaseike, Shizuoka). For $\left[\mathrm{Ca}^{2+}\right]$ measurements, the $\mathrm{Ca}^{2+}$ indicator fluo-3 was excited at $488 \mathrm{~nm}$ through a fiber optics using a $60 \mathrm{~mW}$ argon laser attenuated by $82 \%$, and its emission was detected at $500-600 \mathrm{~nm}$. Confocal $x-y$ images were normally collected at $210-\mathrm{ms}$ intervals. Line-scan $x$ - $t$ images were obtained by repetitive scanning along a horizontal line every $1.1 \mathrm{~ms}$. In prelimi- nary experiments using a model solution, a two-photon excitation of fluo-3 appeared to be negligible at $710-715 \mathrm{~nm}$ and the power levels used for TPP. When fluorescent beads of $0.1 \mu \mathrm{m}$ diameter were excited by pulsed laser light (two-photon excitation in the same optical system), the width of the half-maximal intensity was $0.35 \mu \mathrm{m}$ in $x y$-plane and $0.95 \mu \mathrm{m}$ in $z$-direction. Data analyses were carried out by using $\mathrm{NIH}$ Image (ver. 1.62, NIH, Bethesda, MD, USA).

Solutions and chemicals, The photolysis solution contained (mM) $135 \mathrm{KMS}, 2.0 \mathrm{MgMS}_{2}, 4.0$ $\mathrm{Na}_{2}$ ATP, 0.06-0.075 $\mathrm{CaMS}_{2}$, 0.05 EGTA, 0.03 fluo-3, 0.2 DM-nitrophen, $20 \mathrm{MOPS}$, and $\mathrm{pH}$ 7.2. On one occasion, $\left[\mathrm{Ca}^{2+}\right]$ of the photolysis solution containing $75 \mu \mathrm{M} \mathrm{CaMS}{ }_{2}$ was estimated to be $0.15 \mu \mathrm{M}$ from fluo3 fluorescence intensities measured after the addition of an excess amount $(1 \mathrm{mM})$ of either EGTA $\left(F_{\min }\right)$ or $\mathrm{CaMS}_{2}\left(F_{\max }\right)$ and a dissociation constant value of $0.44 \mu \mathrm{M}$ separately estimated for $\mathrm{Ca}^{2+}$-fluo-3 reaction (not shown). There may, however, be some variation in $\left[\mathrm{Ca}^{2+}\right]$ of the photolysis solution between experiments, depending on the amount of contaminant $\mathrm{Ca}^{2+}$. In practice, the amount of added $\mathrm{CaMS}_{2}$ was adjusted in each experiment to observe occasional spontaneous activity of skinned myocytes that was taken as an indication of significant loading of the sarcoplasmic reticulum (SR) with $\mathrm{Ca}^{2+}$. The $\left[\mathrm{Mg}^{2+}\right]$ in the presence of $150 \mathrm{nM}$ free $\mathrm{Ca}^{2+}$ was calculated to be $83 \mu \mathrm{M}$ under the assumption that the apparent dissociation constant for $\mathrm{Mg}^{2+}$-ATP reaction was $100 \mu \mathrm{M}$ (as assumed by Baylor and Hollingworth [15]) and the apparent dissociation constants of DM-nitrophen for $\mathrm{Ca}^{2+}$ and $\mathrm{Mg}^{2+}$ were, respectively, $5 \mathrm{nM}$ and $2.5 \mu \mathrm{M}$ [14]. During preparation and storage of the solution, care was taken to minimize exposure of DM-nitrophen to room light.

DM-nitrophen (tetrasodium salt) was purchased from Calbiochem (San Diego, CA, USA). fluo-3 (tetrapotassium salt) and NP-EGTA (tetrapotassium salt) from Molecular Probes (Eugene, OR, USA). EGTA (free acid), ryanodine, thapsigargin, and saponin from Sigma (St. Louis, MO, USA).

\section{Results}

We used a new combination of techniques: Twophoton excitation photolysis (TPP) of caged $\mathrm{Ca}^{2+}$, and $\left[\mathrm{Ca}^{2+}\right]$ was monitored with confocal imaging of fluo-3 fluorescence (Fig. 1). Figure 1A shows a transmission image of a skinned ventricular myocyte under exposure to the photolysis solution containing $75 \mu \mathrm{M}$ $\mathrm{CaMS}_{2}$. Spontaneous $\mathrm{Ca}^{2+}$ waves and contraction were occasionally seen in this and many other cells, indicating that the SR was sufficiently loaded with $\mathrm{Ca}^{2+}$. Figure 1, B-D, shows fluo-3 fluorescence im- 

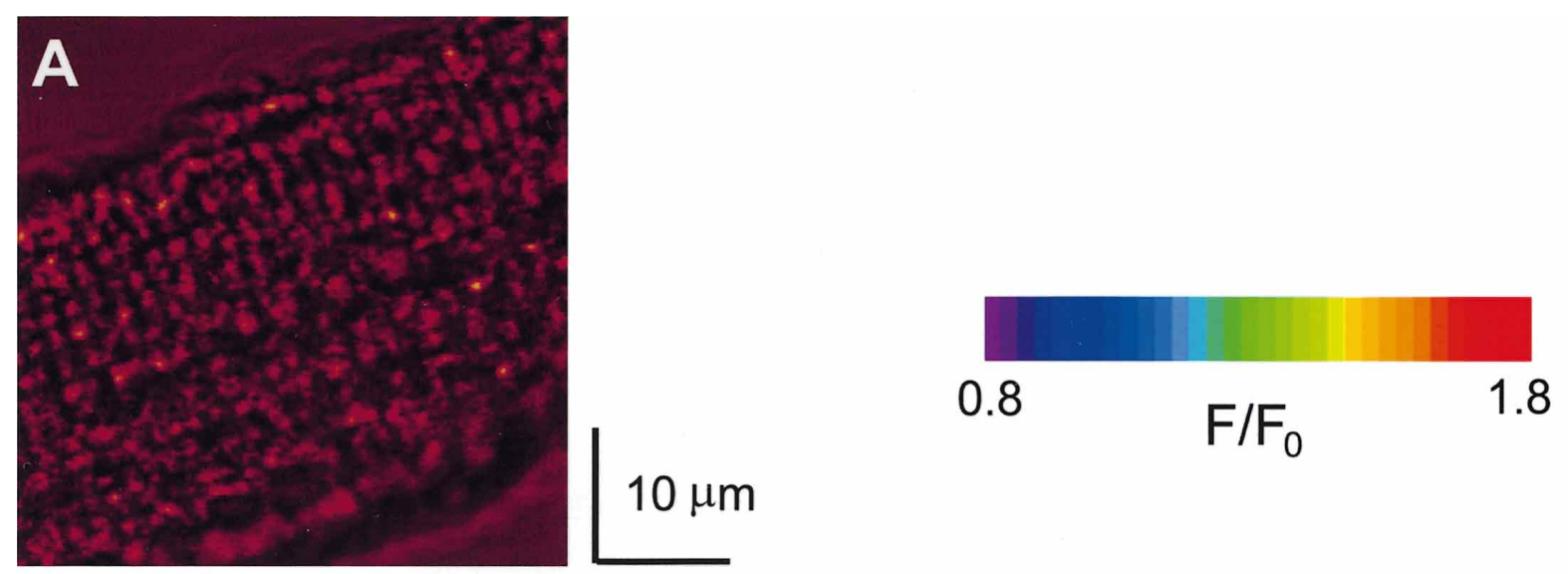

$10 \mu \mathrm{m}$
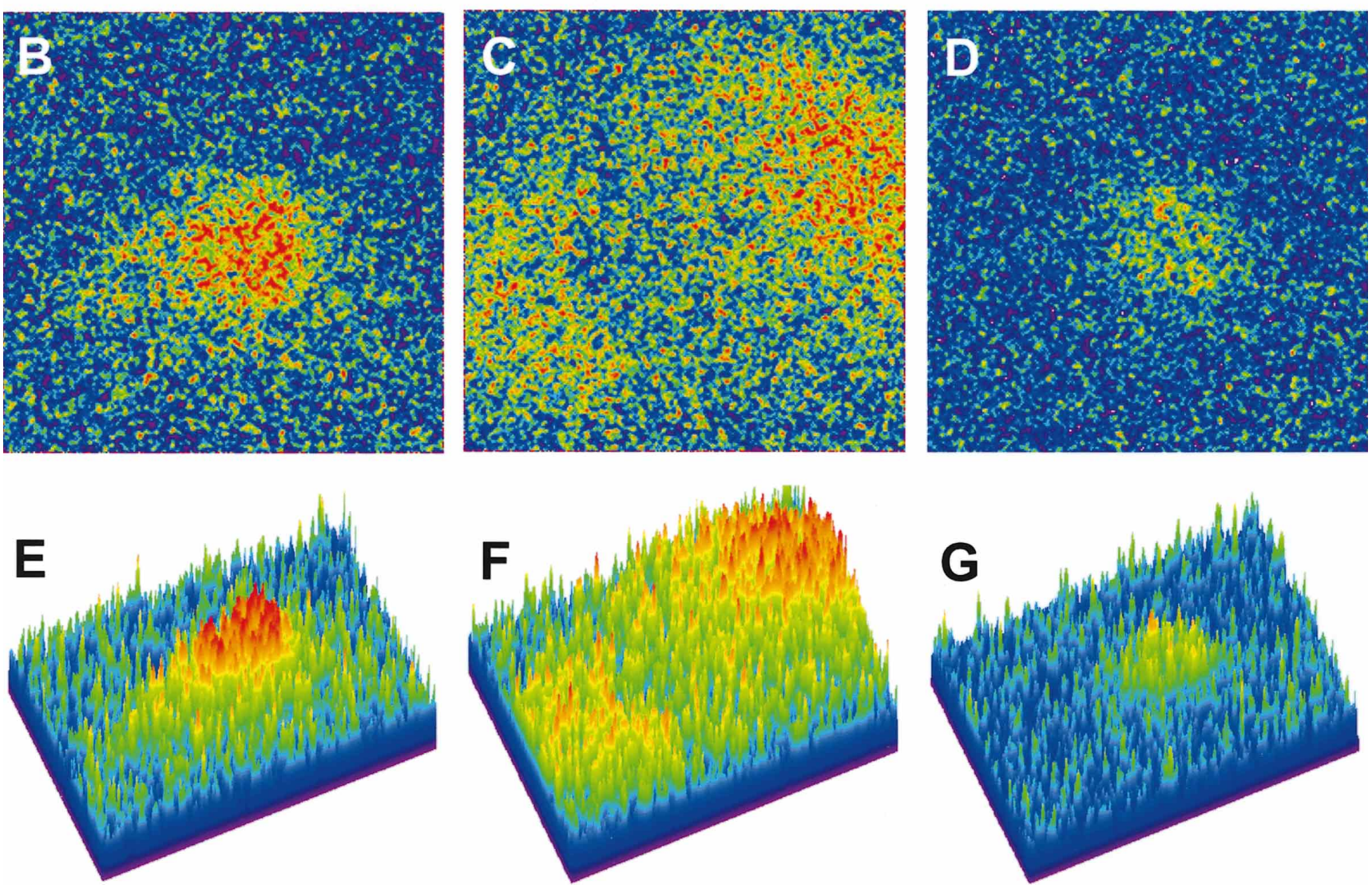

Fig. 1. (A) Transmitted light image of a skinned myocyte. (B-D) confocal images ( $x-y$ scan; $256 \times 256$ pixels, pixel size $0.155 \mu \mathrm{m}$ ) of fluo-3 fluorescence in $F / F_{0}$ unit, and $(E-G)$ their surface plots obtained from the same location of the myocyte. (B, C) Consecutive images (210 ms apart) taken shortly after photolysis in the absence of ryanodine, and (D) image taken shortly after photolysis in the

presence of $10 \mu \mathrm{M}$ ryanodine. (E-G) Surface plots corresponding to (B-D), respectively. For each fluorescence image, four preceding frames were averaged to yield $F_{0}$ of each pixel, and $F / F_{0}$ values were calculated pixel by pixel. Photobleaching during these frames was found to be negligible. Note that calibration bars $(10 \mu \mathrm{m})$ of $x-y$ dimensions are commonly applied to (A-D), but not to (E-G).

ages of the same cell in $F / F_{0}$ unit, fluorescence intensity values $(F)$ normalized to the basal value $\left(F_{0}\right)$, as an index of $\left[\mathrm{Ca}^{2+}\right]$. In $\mathrm{E}-\mathrm{G}$, the surface plots corresponding to B-D, respectively, are shown. In the quiescent state between the events of spontaneous $\mathrm{Ca}^{2+}$ waves, the pulsed laser light of $710 \mathrm{~nm}$ delivered for $64 \mathrm{~ms}$ induced propagating $\mathrm{Ca}^{2+}$ waves (Fig. 1, B and C). An application of ryanodine $(10 \mu \mathrm{M})$ completely suppressed the $\mathrm{Ca}^{2+}$ wave, leaving a small rise of $\left[\mathrm{Ca}^{2+}\right]$ localized only at the site of photolysis (Fig. 1D).

$\mathrm{Ca}^{2+}$ measurements of higher time resolution were carried out in the same myocyte with the line-scan mode (Fig. 2); laser scanning was repeated along a horizontal line shown in Fig. 2A at $1.1 \mathrm{~ms}$ interval. TPP of DM-nitrophen induced a $\mathrm{Ca}^{2+}$ wave propagat- 

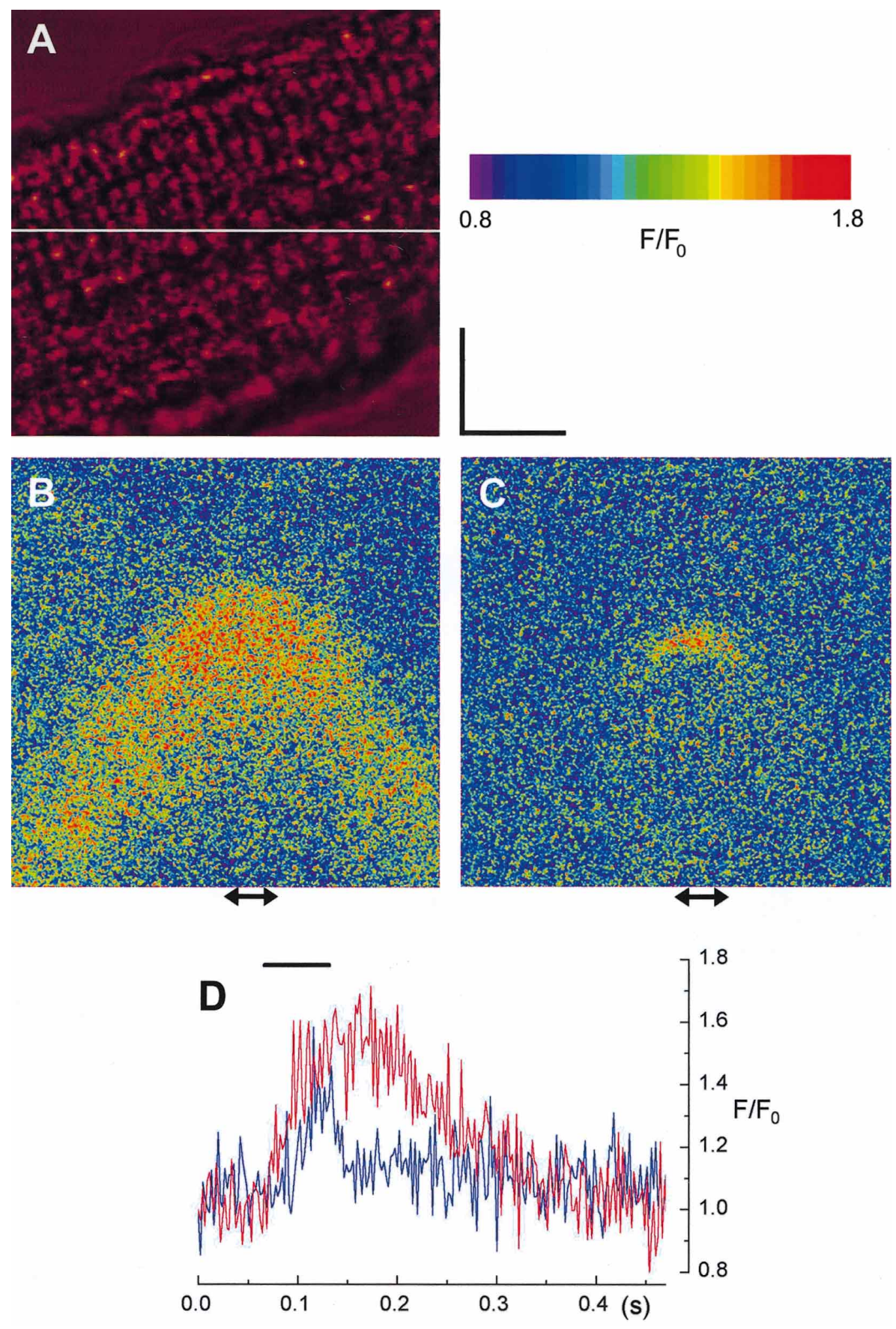

Fig. 2. (A) Transmitted light image of the same skinned were calculated pixel by pixel. Photobleaching during these myocyte as shown in Fig. 1. (B, C) Confocal line-scan frames was found to be negligible. The horizontal calibration images of $\boldsymbol{F} / \boldsymbol{F}_{\mathbf{0}}$ ( $\boldsymbol{x}$ - $\boldsymbol{t}$ scan; $\mathbf{5 1 2} \times \mathbf{5 1 2}$ pixels, pixel size bar indicates $10 \mu \mathrm{m}$ in $(\mathrm{A}-\mathrm{C}$ ), and the vertical bar corre$\mathbf{0 . 0 7 8} \boldsymbol{\mu m} \times \mathbf{1 . 1} \mathbf{m s}$ ) taken along a white line shown in (A) sponds to $10 \mu \mathrm{m}$ in (A) and $140 \mathrm{~ms}$ in (B, C). (D) Time during photolysis. Line-scan images taken in the absence (B) and in the presence of $10 \mu \mathrm{M}$ ryanodine $(\mathrm{C})$ consist of a series of 512 lines scanned at $1.1 \mathrm{~ms}$ interval (from top to bottom). For each line-scan image, two preceding frames were averaged to yield $F_{0}$ of each pixel, and $F / F_{0}$ values courses of $\boldsymbol{F} / \boldsymbol{F}_{0}$ at the site of TPP. Traces shown in red and blue were obtained from $(B)$ and $(C)$, respectively, by averaging 64 horizontal pixels $(=5 \mu \mathrm{m})$, indicated underneath by arrows. The time axes of the two traces have been aligned by the timing of TPP, indicated by a horizontal bar.

ing toward both sides with the velocity of approximately $60 \mu \mathrm{m} / \mathrm{s}$ (Fig. 2B). A time course of local $\left[\mathrm{Ca}^{2+}\right]$ changes at the site of TPP shows that the increase in $\left[\mathrm{Ca}^{2+}\right]$ was sustained for $50-60 \mathrm{~ms}$ after ces- sation of the pulse (red line in Fig. 2D). After an application of $10 \mu \mathrm{M}$ ryanodine, no $\mathrm{Ca}^{2+}$ wave was seen (Fig. 2C), and the local $\left[\mathrm{Ca}^{2+}\right]$ at the site of TPP quickly returned toward the basal level following ter- 
mination of the photolysis pulse (blue line in Fig. 2D). Essentially similar results were obtained in four other myocytes. In a separate experiment, we also examined the effect of $10 \mu \mathrm{M}$ thapsigargin, an inhibitor of the SR $\mathrm{Ca}^{2+}$ pump. The TPP-induced $\mathrm{Ca}^{2+}$ waves were also effectively inhibited by this agent. Overall, these results suggest that we were able to trigger propagating $\mathrm{Ca}^{2+}$ waves by sequential $\mathrm{Ca}^{2+}$-induced $\mathrm{Ca}^{2+}$ release from neighboring ryanodine receptors.

Although the experiments shown in Figs. 1 and 2 used a relatively low concentration of DM-nitrophen $(0.2 \mathrm{mM})$, preliminary TPP experiments were performed in the presence of a higher concentration of DM-nitrophen. In several trials with $1 \mathrm{mM}$ DM-nitrophen and the addition of various concentrations of $\mathrm{CaMS}_{2}$, TPP caused only a local rise of $\left[\mathrm{Ca}^{2+}\right]$ at the focal point with no propagating $\mathrm{Ca}^{2+}$ waves. The reason of this absence of $\mathrm{Ca}^{2+}$ waves was not further investigated in the present study.

\section{Discussion}

In saponin-skinned ventricular myocytes, propagating $\mathrm{Ca}^{2+}$ waves are highly reproducible upon TPP of DM-nitrophen. Local photolysis of caged $\mathrm{Ca}^{2+}$ appears to be a useful tool to study the interactions between adjacent ryanodine receptors (or groups of receptors) with no intervention of $\mathrm{Ca}^{2+}$ influx from the extracellular space, i.e., L- and T-type $\mathrm{Ca}^{2+}$ channels and the $\mathrm{Na}^{+}-\mathrm{Ca}^{2+}$ exchanger. The use of skinned cells has the advantage over intact cells that the intracellular environment is precisely controlled, and hydrophilic compounds can be easily applied to alter properties of $\mathrm{Ca}^{2+}$ release.

In previous TPP studies in intact cells, $1 \mathrm{mM}$ DMnitrophen was introduced into the cytoplasm through a patch pipette $[10,11]$, and global $\mathrm{Ca}^{2+}$ movements were successfully induced by TPP. In the present study, on the contrary, we were unable to observe $\mathrm{Ca}^{2+}$ waves upon TPP of the same concentration (1 mM) of DM-nitrophen as used in the previous studies. This apparent discrepancy may be due to limited intracellular dialysis under a whole-cell patch clamp that could result in significantly lower concentrations of DM-nitrophen in the cytoplasm than in the patch pipette. In skinned myocytes, high concentrations of the caged $\mathrm{Ca}^{2+}$ compound, DM-nitrophen might reduce $\mathrm{Ca}^{2+}$ diffusion to adjacent $\mathrm{Ca}^{2+}$ releasing sites because of its $\mathrm{Ca}^{2+}$ buffering effect. Alternatively, the discrepancy may be attributed to the difference in "intracellular" ionic conditions used. For example, $\left[\mathrm{Mg}^{2+}\right]$ is known to affect $\mathrm{Ca}^{2+}$-induced $\mathrm{Ca}^{2+}$ release; the internal solutions used in the earlier studies did not contain $\mathrm{Mg}^{2+}$, whereas a small amount of $\mathrm{Mg}^{2+}$ was always included in the present study.

Since DM-nitrophen, a photosensitive derivative of EDTA, binds $\mathrm{Mg}^{2+}$ with an affinity only 500 times lower than that for $\mathrm{Ca}^{2+}$, it was required to set $\left[\mathrm{Mg}^{2+}\right]$ of the photolysis solution quite low $(83 \mu \mathrm{M})$ in the present study. Even at this low level of $\left[\mathrm{Mg}^{2+}\right]$, it is calculated that the slightly greater fraction of DM-nitrophen molecules are $\mathrm{Mg}^{2+}$-bound (52\%) before photolysis, in comparison with its $\mathrm{Ca}^{2+}$-bound form (47\%). To produce $\mathrm{Ca}^{2+}$ waves by TPP in the presence of normal cytoplasmic $\left[\mathrm{Mg}^{2+}\right](0.4-0.9 \mathrm{mM}$; e.g., $[16,17])$, it is obviously preferable to use an EGTAbased caged $\mathrm{Ca}^{2+}$ compound. We therefore tested TPP of NP-EGTA [18], but trials with high concentrations of NP-EGTA (1.0-2.2 mM) were not successful (unpublished observation). This could be explained by (i) the same reason for the case of high concentrations of DM-nitrophen, i.e., $\mathrm{Ca}^{2+}$ buffering effect, and/or (ii) its low extinction coefficient causing insufficient $\mathrm{Ca}^{2+}$ release from the caged compound upon TPP [19]. A newly synthesized caged $\mathrm{Ca}^{2+}$ compound, dimethoxynitrophenyl-EGTA-4 [19], which is not commercially available at present, may solve the problem related to $\mathrm{Mg}^{2+}$.

In conclusion, to investigate how elementary $\mathrm{Ca}^{2+}$ events produce global $\mathrm{Ca}^{2+}$ movements, we developed a new combination of techniques: two-photon excitation photolysis of caged $\mathrm{Ca}^{2+}$ in skinned cardiac myocytes. $\mathrm{Ca}^{2+}$ waves were highly reproducible with TPP of caged $\mathrm{Ca}^{2+}$, and possible modulators for $\mathrm{Ca}^{2+}$ release and uptake could be easily examined. Furthermore, it is suggested that "intracellular" ionic conditions, including the concentration of caged $\mathrm{Ca}^{2+}$ compound itself, should be carefully optimized.

This work was financially supported in part by a Grant-inAid for the High-Tech Research Center from the Ministry of Education, Science, Sports and Culture of Japan to Nihon University, and a grant from the Salt Science Research Foundation (No. 0039).

\section{REFERENCES}

1. Cheng $\mathrm{H}$, Lederer $\mathrm{W}$, and Cannell MB: Calcium sparks: elementary events underlying excitation-contraction coupling in heart muscle. Science 262: 740-744, 1993

2. Nelson MT, Cheng $H$, Rubart M, Santana LF, Bonov $A D$, Knot $\mathrm{HJ}$, and Lederer $\mathrm{WJ}$ : Relaxation of arterial smooth muscle by calcium sparks. Science 270: 633637, 1995

3. Lipp P and Niggli E: Submicroscopic calcium signals as fundamental events of excitation-contraction coupling in guinea-pig cardiac myocytes. J Physiol (Lond) 492: 31-38, 1996

4. Arnaudeau S, Macrez-Leprêtre N, and Mironneau J: Activation of calcium sparks by angiotensin II in vascu- 
lar myocytes. Biochem Biophys Res Comm 222: 809815, 1996

5. Parker I, Choi J, and Yao Y: Elementary events of InsP $\mathrm{P}_{3^{-}}$ induced $\mathrm{Ca}^{2+}$ liberation in Xenopus oocytes: hot spots, puffs and blips. Cell Calcium 20: 105-121, 1996

6. Shirokova N, and Ríos E: Small event $\mathrm{Ca}^{2+}$ release: a probable precursor of $\mathrm{Ca}^{2+}$ sparks in frog skeletal muscle. J Physiol (Lond) 502: 3-11, 1997

7. Imaizumi $Y$, Torii $Y$, Ohi $Y$, Nagano N, Atsuki K, Yamamura $\mathrm{H}$, Muraki $\mathrm{K}$, Watanabe $\mathrm{M}$, and Bolton TB: $\mathrm{Ca}^{2+}$ images and $\mathrm{K}^{+}$current during depolarisation in smooth muscle cells of guinea-pig vas deferens and urinary bladder. J Physiol (Lond) 510: 705-719, 1998

8. Koizumi S, Bootman MD, Bobanovic LK, Schell MJ, Berridge MJ, and Lipp P: Characterization of elementary $\mathrm{Ca}^{2+}$ release signals in NGF-differentiated PC12 cells and hippocampal neurones. Neuron 22: 125-137, 1999

9. Berridge MJ: Elementary and global aspects of calcium signalling. J Physiol (Lond) 499: 291-306, 1997

10. Lipp P and Niggli E: Fundamental calcium release events revealed by two-photon excitation photolysis of caged calcium in guinea-pig cardiac myocytes. J Physiol (Lond) 508: 801-809,1998

11. Nakayama S, Akita T, Lu F-M, and Kuba K: Two-photon excitation calcium-imaging and uncaging in neurones. Jpn J Physiol 49, S37, 1999

12. Lukyanenko $V$ and Györke S: $\mathrm{Ca}^{2+}$ sparks and $\mathrm{Ca}^{2+}$ waves in saponin-permeabilized rat ventricular myocytes. J Physiol (Lond) 521: 575-585, 1999

13. Konishi M and Berlin JR: Ca transients in cardiac myocytes measured with a low affinity fluorescent indicator, furaptra. Biophys J 64: 1331-1343, 1993

14. Kaplan JH and Ellis-Davies GCR: Photolabile chelators for the rapid photorelease of divalent cations. Proc Natl Acad Sci USA 85: 6571-6575, 1988

15. Baylor SM and Hollingworth S: Model of sarcomeric $\mathrm{Ca}^{2+}$ movements, including ATP $\mathrm{Ca}^{2+}$ binding and diffusion, during activation of frog skeletal muscle. J Gen Physiol 112: 297-316, 1998

16. Nishimura $H$, Matsubara $T$, Ikoma $Y$, Nakayama $S$, and Sakamoto N: Effects of prolonged application of isoprenaline on intracellular free magnesium concentration in isolated heart of rat. $\mathrm{Br} \mathrm{J}$ Pharmacol 109: 443448, 1993

17. Watanabe $\mathrm{M}$ and Konishi $\mathrm{M}$ : Intracellular calibration of the fluorescent $\mathrm{Mg}^{2+}$ indicator furaptra in rat ventricular myocytes. Pflügers Arch 442, 2001, in press

18. Ellis-Davies GCR and Kaplan JH: Nitrophenyl-EGTA: a photolabile chelator that selectively binds $\mathrm{Ca}^{2+}$ with high affinity and releases it rapidly upon photolysis. Proc Natl Acad Sci USA 91: 187-191, 1994

19. DelPrince F, Egger M, Ellis-Davies GCR, and Niggli E: Two-photon and UV-laser flash photolysis of the $\mathrm{Ca}^{2+}$ cage, dimethoxynitrophenyl-EGTA-4. Cell Calcium 25: 85-91, 1999 